hypothyroidism, and to Mrs. Kathleen Hume for valuable technical assistance. Mr. R. G. McGuire, Department of Psychological Medicine, University of Glasgow, gave advice regarding the statistical analysis.

\section{REFERENCES}

Abell, L. L., Levy, B. B., Brodie, B. B., and Kendall, S. E. (1958). In Standard Methods in Clinical Chemistry, edited by $M$. Reiner, vol. 2, p. 26. Academic Press, New York.

Biggs, R., and Macfarlane, R. G. (1957). Human Blood Coagulation and its Disorders, 2nd ed., p. 389. Blackwell, Oxford.

Branwood, A. W., and Montgomery, G. L. (1956). Scot. med. F., 1, 367. Clement, W. E., and McNicol, G. P. (1959). F. clin. Path., 12, 544.

Douglass, R. C., and Jacobson, S. D. (1957). F. clin. Endocr., 17, 1354.
Fahr, G. (1932). Amer. Heart. 7., 8, 91

Fishberg, A. M. (1924). f. Amer. med. Ass., 82, 463.

Hume, R. (1958). Brit. Heart f., 20, 15

(1961). F. clin. Path., 14, 167

La Due, J. S. (1943). Ann. intern. Med., 18, 332.

Lund, E., Geill, T., and Andresen, P. H. (1961). Lancet, 2, 1383.

Orr, F. R. (1962). Ibid., 2, 1012.

Salter, W. T. (1941). New Engl. F. Med., 225, 709.

Sawyer, W. D., Fletcher, A. P., Alkjaersig, N., and Sherry, S. (1960). 7. clin. Invest., 39, 426

Smyth, C. J. (1938). Amer. Heart F., 15, 652.

Wallach, E. E., Lubash, G. D., Cohen, B. D., and Rubin, A. L. (1958) F. Amer. med. Ass., 167, 1921.

Wayne, E. J. (1960). Brit. med. F., 1, 78.

Willius, F. A., and Haines, S. F. (1925). Amer. Heart F., 1, 67.

Wood, P. H. (1956). Diseases of the Heart and Circulation, 2nd ed. p. 891. Eyre and Spottiswoode, London.

\title{
Reduced Platelet Survival in Patients with Starr-Edwards Prostheses*
}

\author{
HARRY LANDER, $†$ M.R.A.C.P. ; RAELENE L. KINLOUGH,ł M.B., B.S. ; H. N. ROBSON,§ F.R.C.P., F.R.A.C.P.
}

Brit. med. F., 1965, 1, 688-689

It is well recognized that patients with valvular disease of the heart are particularly susceptible to the complications of thrombosis and embolism, especially if the mitral orifice is stenosed. In recent years valvular repair by a variety of prosthetic procedures allowed the hope that such complications might be avoided. Unfortunately, thrombosis and embolism have continued to occur, often at a long interval after successful operations of this type. The finding of thrombi attached or in close proximity to artificial prostheses has led to the continued modification of such prostheses and operative techniques and to the extensive use of long-term anticoagulant therapy postoperatively (Lancet, 1962).

As many such thrombi have been composed mainly of platelets and fibrin, we have investigated the behaviour and survival of radiochromate-labelled platelets in patients who have undergone successful valve replacement with Starr-Edwards ball-valve prostheses (Starr and Edwards, 1961 ; Starr et al., 1962).

\section{Subjects Studied and Methods}

Eight studies have been carried out in seven subjects. Two were males and five females. Their ages ranged from 24 to 64 years. In each instance the operation was performed by $\mathrm{Mr}$. H. D'Arcy Sutherland with the assistance of members of the Cardiac Surgery Unit of the Royal Adelaide Hospital. In five

\footnotetext{
* Supported by a grant-in-aid (G251/43) from the National Heart Foundation of Australia.

t Reader in Medicine, Department of Medicine, University of Adelaide, South Australia.

$\ddagger$ Research Assistant, National Heart Foundation of Australia.

$\$$ Professor of Medicine, Department of Medicine, University of Adelaide, South Australia.
}

subjects the mitral valve had been replaced and in two the aortic. All had been considerably improved by operation, and none was in cardiac failure. One subject (R. J.) was studied twice. Details relating to each subject are included in the Table.

Platelets from each subject were labelled with 70-100 microcuries of radiochromate in vitro and reinfused into the donor, in whom their behaviour, survival, and distribution in the body were studied.

Details of the procedure employed have been described previously (Davey and Lander, 1963), except that the blood from which the platelets were separated was collected in the more acid solution of acid-citrate-dextrose (A.C.D. " $S$ ") suggested by Aster and Jandl (1964), instead of in a solution of ethylenediaminetetra-acetic acid (E.D.T.A.).

Platelet radioactivity was measured in samples of blood collected at frequent intervals for four hours following infusion of the labelled platelets and at daily intervals for at least 10 days. In addition, activity over the heart, lungs, liver, spleen, and sacrum was determined daily by external scintillation counting (I ander and Davey, 1964a). Platelet counts were performed on all samples of blood by the method of Brecher and Cronkite (1950).

\section{Results}

In all subjects infusion of the labelled platelets was followed by the normal phenomenon of transient "segregation" and subsequent re-entry into circulation of a proportion of the labelled platelets (Davey and Lander, 1964). However, as found by Aster and Jandl (1964), the degree of segregation is less when A.C.D. " $S$ " is used as anticoagulant than when E.D.T.A. is used.

\begin{tabular}{|c|c|c|c|c|c|c|c|c|}
\hline Subject & Sex & Age & $\begin{array}{c}\text { Valve } \\
\text { Replaced }\end{array}$ & $\begin{array}{c}\text { Time } \\
\text { After } \\
\text { Operation } \\
\text { (W eeks) }\end{array}$ & Anticoagulant & Thrombosis or Embolism & $\begin{array}{l}\text { Platelet Count (per c.mm.) } \\
\text { Mean and Range }\end{array}$ & $\begin{array}{l}\text { Platelet } \\
\text { Survival }\end{array}$ \\
\hline J.K. & $\stackrel{\mathrm{F}}{\mathrm{F}}$ & $\begin{array}{l}49 \\
59\end{array}$ & $\begin{array}{l}\text { Mitral } \\
\text { Mitral }\end{array}$ & $\begin{array}{l}25 \\
29\end{array}$ & $\begin{array}{l}\text { Phenindione } \\
\text { Phenindione }\end{array}$ & $\begin{array}{l}\text { Cerebral; pre-operative and early post- } \\
\text { operative }\end{array}$ & $\begin{array}{l}313,000(207,000-369,000) \\
232,000(183,000-345,000)\end{array}$ & $\begin{array}{l}\text { Normal } \\
\text { Normal }\end{array}$ \\
\hline $\begin{array}{l}\text { S.R. } \\
\text { R.J. }\end{array}$ & $\begin{array}{l}\mathrm{F} \\
\mathrm{M}\end{array}$ & $\begin{array}{l}24 \\
64\end{array}$ & $\begin{array}{l}\text { Mitral } \\
\text { Aortic }\end{array}$ & $\left\{\begin{array}{l}32 \\
45 \\
48\end{array}\right.$ & $\begin{array}{l}\text { Phenindione } \\
\text { Nil } \\
\text { Phenindione }\end{array}$ & Cerebral; post-operative* & $\begin{array}{l}240,000(180,000-327,000) \\
230,000(168,000-294,000) \\
251,000(207,000-324,000)\end{array}$ & $\begin{array}{l}\text { Norma } \\
\text { Normal } \\
\text { Normal }\end{array}$ \\
\hline $\begin{array}{l}\text { S.M. } \\
\text { R.L. } \\
\text { P.B. }\end{array}$ & $\begin{array}{l}\mathrm{F} \\
\mathrm{F}\end{array}$ & $\begin{array}{l}51 \\
37 \\
52\end{array}$ & $\begin{array}{l}\text { Aortic } \\
\text { Mitral } \\
\text { Mitral }\end{array}$ & $\begin{array}{r}46 \\
46 \\
52\end{array}$ & $\begin{array}{l}\text { Nil } \\
\text { Phenindione } \\
\text { Phenindione }\end{array}$ & Cerebral; pre-operative & $\begin{array}{l}214,000(180,000-273,000) \\
254,000(207,000-360,000) \\
244,000(180,000-360,000)\end{array}$ & $\begin{array}{l}\text { Reduced } \\
\text { Reduced } \\
\text { Reduced }\end{array}$ \\
\hline
\end{tabular}

* See text. 
The survival curves obtained in the eight studies are illustrated in the Figure.

All points in the survival curves of subjects J. K., E. K., and $S$. $R$. fell within the curvilinear range found in normal subjects. All three subjects were receiving phenindione in closes adequate to maintain their prothrombin index between 10 and $25 \%$ of normal.

Subject R. J. had been placed on phenindione therapy 10 days after operation, and this was discontinued after 34 weeks. Some six weeks later he presented with a sudden onset of aphasia and a mild right hemiparesis. A plateletsurvival study was begun six days after this episode. After its completion, phenindione therapy was recommenced and a second survival study was undertaken. On both occasions the platelet-survival pattern fell within normal limits.

In subjects S. M., R. L., and P. B. the platelet half-life was reduced, but in each instance platelet radioactivity persisted in circulation for the usual period of 9 to 11 days.

External scintillation counting revealed a more marked uptake of radioactivity in the spleen and to a less extent in the liver in those subjects with reduced survivals than in normal persons or in those with valvular prostheses who manifested a normal survival pattern.

\section{Discussion}

The pattern of the survival curves in subjects S.M., R.L., and $P$. B. suggests that, although many of the labelled platelets survived for their natural life-span of 9 to 11 days, a considerable number of platelets were being prematurely removed from circulation in a random fashion (Lander and Davey, 1964b ; Davey, Lander, and Robson, 1964). This increased platelet loss was presumably matched by increased production, for none of the patients was thrombocytopenic. There was no suggestion that these abnormal findings were related either to replacement of a particular valve or to the administration of phenindione. However, it is interesting to note that abnormal results were obtained in those subjects in whom prostheses had been in place for the longest period (see Table).

The premature removal of platelets in these subjects could be due to their being consumed in thrombus formation, for similar survival curves have been observed in association with intravascular thrombosis (Adelson, Rheingold, Parker, Buenaventura, and Crosby, 1961 ; Firkin, 1963 ; O’Neill and Firkin, 1964). It is possible that in these three individuals the abnormal platelet-survival patterns are an indication that continuing platelet deposition and thrombus formation are occurring in the region of the prosthesis.

It could also be postulated that platelets are being "damaged" in circulation by the Starr-Edwards valve. Although no morphological abnormality of the subjects' platelets or red cells was observed in these studies, external scintillation counting showed that much more radioactivity accumulated in the spleen (and liver) of those cases with reduced survivals than in normal subjects or in those with valve prostheses and normal survivals. This could suggest that in the affected subjects a proportion of their platelets are being damaged in circulation and then sequestered in reticuloendothelial tissue.

However, since such "damaged" platelets might well be more liable to local deposition as well as to reticuloendothelial sequestration, both these mechanisms of removal could be operating simultaneously. 